\title{
HOUSEHOLDS PERCEPTION ON THE GENERATION AND DISPOSAL OF SOLID WASTE IN LAFIA METROPOLIS OF NASARAWA STATE, NIGERIA
}

\author{
Ezekiel Ayiwulu*, Dahiru M. Kabiru and Abdullahi S. Bara'atu \\ Department of Geography, Federal University of Lafia, Nigeria \\ ${ }^{*}$ Corresponding author email: eayiwulu@gmail.com
}

Cite this article:

Ezekiel A., Dahiru M.K., Abdullahi S.B. (2021), Households Perception on the Generation and Disposal of Solid Waste in Lafia Metropolis of Nasarawa State, Nigeria. African Journal of Environment and Natural Science Research 4(4), 16-26. DOI: 10.52589/AJENSRIFSP0F7D.

\section{Manuscript History}

Received: 25 July 2021

Accepted: 12 Aug 2021

Published: 21 Aug 2021

Copyright () 2020 The Author(s). This is an Open Access article distributed under the terms of Creative Commons AttributionNonCommercial-NoDerivatives 4.0 International (CC BY-NC-ND 4.0 ), which permits anyone to share, use, reproduce and redistribute in any medium, provided the original author and source are credited.
ABSTRACT: Proper solid waste generation and disposal are key components of effective management of municipal solid waste. This study examined households' perception of the generation and disposal of solid waste in the Lafia metropolis. A systematic random sampling method was adopted in selecting respondents. A well-structured questionnaire was administered to 240 selected households heads within the Lafia metropolis which includes four electoral wards (Chiroma, Gayam, Makama and Zanwa). Each of the four electoral wards was divided into three units (totalling 12 units) and administered 20 samples of the questionnaire. The data were analyzed using descriptive statistics. The findings showed the dominance of males over females in the study area. Ages 30 to 59 constitutes over $70 \%$ of the sampled population. About half (49.58\%) of the respondents were civil servants. More than half of the respondents (51.25\%) reported that the waste they generate is food waste. $46.25 \%$ of the respondents use plastic containers as their waste storage facilities. $51.67 \%$ of the respondents indicated getting infected by malaria parasites as a result of the improper location of dumpsites (which serves as breeding sites for disease vectors) within their vicinity. On the basis of the findings, it is recommended that relevant government agencies should provide adequate enlightenment on proper waste generation and disposal, adequate designated dumpsites and collection points, and the need to improve the monthly environmental sanitation exercise in the metropolis.

KEYWORDS: Solid waste, Household, Disposal, Dumpsite, Respondents 


\section{INTRODUCTION}

Globally, waste generation rates are rising. In the year 2016, the world's cities generated 2.01 billion tonnes of solid waste, amounting to 0.74 kilograms per person per day (World Bank, 2019). About half of the world's population (3.5 billion) are without access to waste management services, and open dumping remains the prevalent waste-disposal method in most developing countries (UNEP, 2005). The amount of wastes generated each year is staggering. No one really knows how much waste humans generate, but much of it originates from the developed countries (Nag and Vizayakumar, 2005). The wastes we produce are poorly managed globally, especially in developing countries, which are causing serious environmental pollution (Giusti, 2009). Generations of municipal solid waste increase in line with the developmental rate of any country and African countries are now faced with a huge amount of municipal solid waste which has a direct effect on human health, safety and environment (Bello et al., 2016). In sub-Saharan Africa, particularly Nigeria, solid waste generation and its likely effects on the health, quality of the environment and the urban landscape have become burning national issues. Major cities in sub-Saharan Africa are grappling with mounting heaps of wastes dumped indiscriminately, and these wastes emanate from households or domestic sources, schools, markets, shopping and business centres, etc (Kabiru, 2019). The increase in population, the rapid economic growth and the rise in community living standards accelerate municipal solid waste generation in developing cities (Minghua et al., 2009). Solid waste management is one of the most challenging issues in urban cities, which are facing serious pollution problems due to the generation of huge quantities of solid waste (Kumar et al., 2009). The quantity of municipal solid waste has increased greatly with the improved lifestyle and social status of the populations in urban areas (Sharholy et al., 2007). In view of the serious adverse environmental consequences of the practice of wastes dumping and disposal, once it is generated, must be collected, processed and disposed of (Ogah et al., 2020). The poor conditions of municipal solid waste in cities of developing countries are represented by the accumulation of waste in the streets, a low waste collection rate, and the random dumping or burning of trash in open spaces (Henry et al., 2006). The rate of waste generation in Malaysia is increasing, covering community activities such as commercial, institutional, industrial and markets (Zaini, 2011). Household solid waste is highly heterogeneous and generally dependent on the socioeconomic status of the households (Ahmed and Ali, 2004). Solid wastes generally constitute man's unwanted materials that need to be collected and properly managed. It consists of substances, materials and objects considered as worthless or defective and of no or less value for human economic activities at any point in time. Apart from constituting an eyesore to the urban environment, it constitutes health hazards and threatens the health of man and animals (Ali et al., 2016).

The magnitude of the solid waste problem in Nigeria is enormous. There are no public waste bins, as the amount of trash that accumulates in a matter of hours would be more than waste collectors could haul in a day (Emankhu and Yamusa, 2018). In Nigeria, considerable volumes of wastes are generated at an alarming rate due to increased urbanization (Oladipo et al., 2011). According to studies carried out by Nnaji (2015), the rate of solid waste generation in Nigeria has been put at an average value of $0.49 \mathrm{kilogram} / \mathrm{capital} / \mathrm{day}$. In their study of Lafia metropolis, Ogah et al., (2014) reported that the town has experienced increasing volumes of solid waste generation over the years, and with the establishment of Nasarawa Urban Development Board in 1996, one would have expected waste management practices to improve, but most parts of the town still look filthy. 
The study aims at assessing the perception of households on the generation and disposal of solid wastes in the Lafia metropolis with the following objectives:

i. To assess the socio-economic and demographic characteristics of respondents

ii. To examine the solid waste composition and disposal methods in the Lafia metropolis

iii. To examine the environmental health implication of waste dumpsites

\section{MATERIALS AND METHODS}

\section{Study Area}

Lafia town is the headquarters of the Lafia local government area, and also the capital city of Nasarawa State in north-central Nigeria. It is located between latitudes $8^{0} 28^{\prime} \mathrm{N}$ and $8^{0} 30^{\prime} \mathrm{N}$ to longitudes $8^{0} 29^{\prime} \mathrm{E}$ and $8^{0} 32^{\prime} \mathrm{E}$. The local government area has a population of 330,712 (NPC, 2006), and is bordered by three local government areas; Wamba in the north, Nassarawa Eggon in the north-west, Obi in the south, Doma in the south-west, and Plateau state in the east (Figure 2).

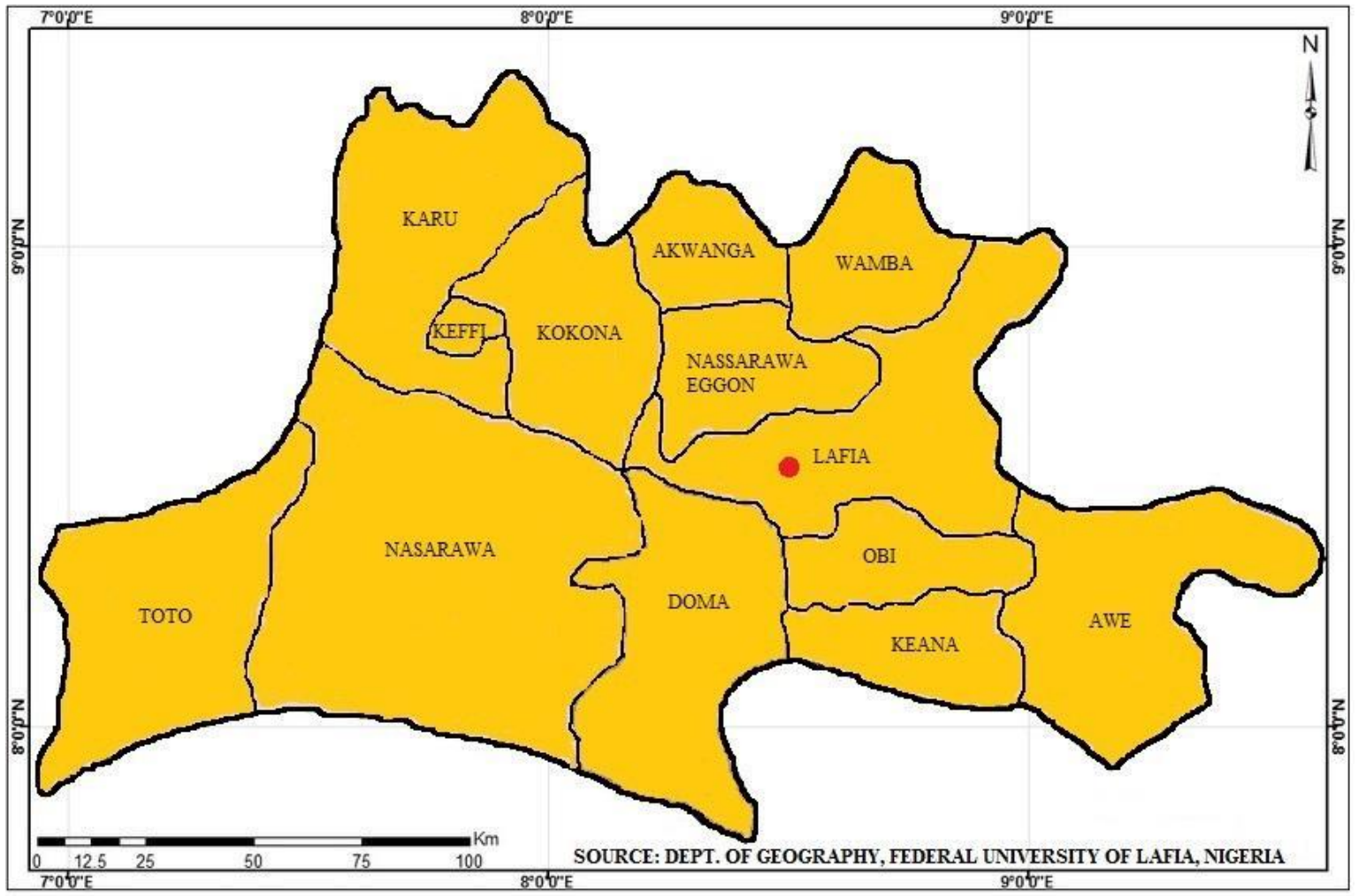

MAP OF NASARAWA STATE SHOWING THE SAMPLING AREA (LAFIA LGA)

Fig. 1: Map of Nasarawa state showing Lafia local government area 


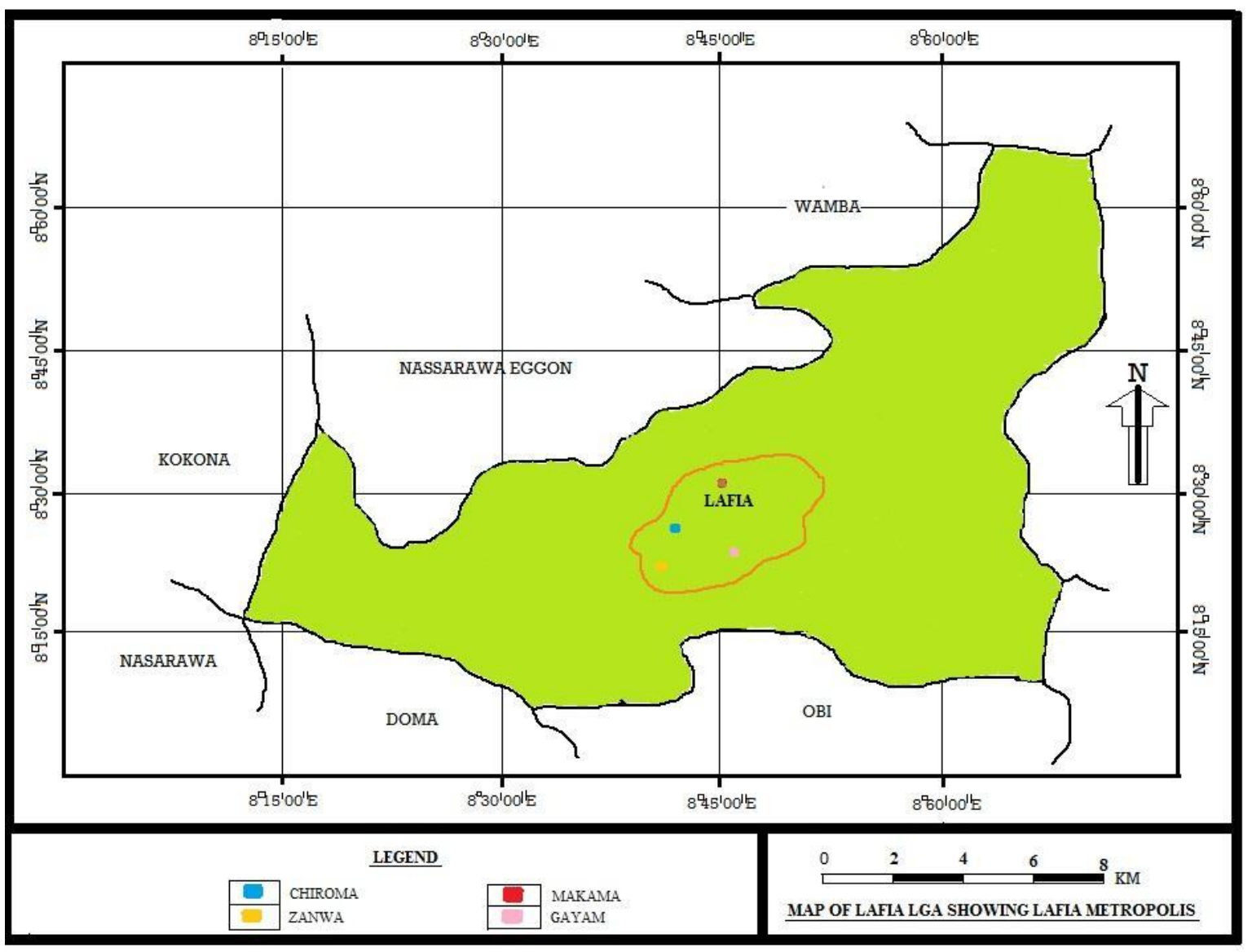

Fig. 2: Map of Lafia metropolis showing the sampled areas

Lafia falls within the southern guinea savanna and has an annual precipitation range of 1000 to $1500 \mathrm{~mm}$. Its mean annual temperature range falls between $24^{\circ} \mathrm{C}$ to $33^{\circ} \mathrm{C}$ and has a soil type that is predominantly sandy loam (Akomolafe and Rahmad, 2020). Nasarawa State shares the same geologic features with the Jos Plateau to the north and belongs to the Benue formation in the southern zone (Ezekiel and Dominic, 2014). Lafia is geologically a part of the lower Benue trough and the major occupations of the inhabitants are civil service, farming, mining, artisanry, and fishing.

\section{METHODOLOGY}

Sources and Types of Data: The study utilized both primary and secondary sources of data. A well-structured questionnaire was designed to obtain information on; (a) the demographic and socioeconomic characteristics of household heads (b) solid waste generation (c) solid waste disposal and health implications. Interviews, field observation, photographs and GPS were also employed for the study. A systematic random sampling method was adopted in administering 240 samples of questionnaires to 240 household heads.

Sample Size Determination: Lafia metropolis is made up of 4 electoral wards out of the 13 electoral wards in Lafia local government area. The study concentrated on the 4 electoral wards 
in the metropolis; Chiroma, Gayam, Makama, and Zanwa. Each of the electoral wards under consideration was divided into three units by randomly selecting from the polling units at a distance of 10 minutes by foot. Each of the 12 polling units was allocated 20 questionnaires and administered on the basis of households which were systematically selected by assigning numbers (1 to 30 ). Out of the 30 houses marked, numbers $3,6,9,12,15,18,21,24,27$, and 30 were not administered questionnaires.

Data Analysis: The study employed both quantitative and qualitative methods of data presentation and analysis. Simple percentages were used to determine the frequency of occurrence of particular responses in relation to questions raised in the questionnaire.

Table 1: Electoral wards and geographic coordinates

\begin{tabular}{|c|c|c|c|c|c|}
\hline & $\begin{array}{l}\text { Coordinates/Altitu } \\
\text { des }\end{array}$ & $\begin{array}{l}\text { Latitude } \\
\text { (North) }\end{array}$ & $\begin{array}{l}\text { Longitude } \\
\text { (East) }\end{array}$ & $\begin{array}{l}\text { Altitude } \\
\text { (Metre) }\end{array}$ & \\
\hline $\begin{array}{l}\text { Electoral } \\
\text { Ward }\end{array}$ & Polling Unit & & & & $\begin{array}{l}\text { No. of } \\
\text { Questionnaire }\end{array}$ \\
\hline \multirow{3}{*}{ Chiroma } & Tudun Kauri & $8^{0} 29.343$ & $8^{0} 32.021$ & 182 & 20 \\
\hline & Low-cost & $8^{0} 30.098$ & $8^{0} 31.713$ & 217 & 20 \\
\hline & $\begin{array}{l}\text { Millionaire's } \\
\text { Quarters }\end{array}$ & $8^{0} 30.849$ & $8^{0} 30.519$ & 174 & 20 \\
\hline \multirow{3}{*}{ Gayam } & Rimi Uku & $8^{0} 29.685$ & $8^{0} 30.597$ & 185 & 20 \\
\hline & UAC Road & $8^{0} 30.467$ & $8^{0} 29.161$ & 179 & 20 \\
\hline & Tudun Gwandara & $8^{0} 30.600$ & $8^{0} 30.541$ & 185 & 20 \\
\hline \multirow{3}{*}{ Makama } & Workers' Village & $8^{0} 28.861$ & $8^{0} 30.219$ & 178 & 20 \\
\hline & Tudun Amba & $8^{0} 29.040$ & $8^{0} 30.287$ & 181 & 20 \\
\hline & Kofar Kaura & $8^{0} 29.398$ & $8^{0} 30.666$ & 165 & 20 \\
\hline \multirow{3}{*}{ Zanwa } & Kofar Liman & $8^{0} 29.372$ & $8^{0} 30.521$ & 160 & 20 \\
\hline & Kofar Zanwa & $8^{0} 29.433$ & $8^{0} 30.629$ & 168 & 20 \\
\hline & Kofar Zuba & $8^{0} 29.475$ & $8^{0} 30.500$ & 165 & 20 \\
\hline
\end{tabular}

Source: Authors' fieldwork

\section{RESULTS AND DISCUSSION}

\section{Socio-Economic and Demographic Characteristics of Respondents}

The dominance of males (74.60\%) over females (25.40) signifies that the household heads were mainly male. Table 3 showed an age range of 30-39 to 50-59 accounting for $77.92 \%$ of the respondents. The sampled respondents obtained at least one form of education, except $11.67 \%$ that had no formal education. $71.25 \%$ of the respondents had obtained a secondary education and above and it, therefore, implies that the literacy rate is high and that could be attributed to the rapid urbanization of Lafia town, which also shows that the respondents ought to have sufficient knowledge of proper solid waste generation and disposal. About half $(49.58 \%)$ of the sampled respondents are civil servants while those in one form of business or the other (trading/business) constitutes $35.00 \%$. 
The table also revealed the average income of respondents per month. $25.42 \%$ of the respondents constitute those that earned less than $\mathrm{N} 18,000$, followed by those that earned above $\mathrm{N} 97,000$ which accounted for $21.70 \%$, and $20.83 \%$ represents those that earned $\mathrm{N} 58,000$ $\mathrm{N} 77,000.12 .50 \%$ earned $\mathrm{N} 38,000-\mathrm{N} 57,000,10.80 \%$ earned $\mathrm{N} 18,000-\mathrm{N} 37,000$, and $8.75 \%$ earned $\mathrm{N78,000}-\mathrm{N} 97,000$. It means above $74 \%$ of the respondents earned more than $\mathrm{N} 18,000$ that is perceived to be the national minimum wage being paid by most Nigerian states including Nasarawa state. This implies that the majority of the respondents have the income to purchase household resources to meet up daily needs and hence, generates more waste. Household sizes of 1-2, 3-4 and 5-6 accounted for 76.08\%. This could be attributed to the high literacy rate and cosmopolitan nature of Lafia city. 7-8, 9-10 and above 10 persons, accounted for $23.92 \%$ which translates to more consumption of resources and waste generation.

Table 2: Socio-economic and demographic characteristics of respondents

\begin{tabular}{|l|l|l|l|}
\hline Variable & Characteristics & Frequency & Percentage \\
\hline Gender & Male & 179 & 74.60 \\
& Female & 61 & 25.40 \\
\hline Age group & $10-19$ & 3 & 1.25 \\
& $20-29$ & 21 & 8.75 \\
& $30-39$ & 59 & 24.58 \\
& $40-49$ & 76 & 31.67 \\
& $50-59$ & 52 & 21.67 \\
& 60 and above & 29 & 12.08 \\
\hline Educational status & No formal education & 28 & 11.67 \\
& Primary & 41 & 17.08 \\
& Secondary & 102 & 42.50 \\
& Tertiary & 69 & 28.75 \\
\hline Occupation & Civil servants & 119 & 49.58 \\
& Trading/business & 84 & 35.00 \\
& Farming & 31 & 12.92 \\
& Others & 6 & 2.50 \\
\hline Income level (N) & Less than 18,000 & 61 & 25.42 \\
& $18,000-37,000$ & 26 & 10.80 \\
& $38,000-57,000$ & 30 & 12.50 \\
& $58,000-77,000$ & 50 & 20.83 \\
Number of people & $1-2$ & 21 & 8.75 \\
per household & $3-4$ & 52 & 21.70 \\
\hline & $5-6$ & 51 & 11.67 \\
& $7-8$ & 98 & 40.83 \\
& $9-10$ & 47 & 23.58 \\
& Above 10 & 28 & 17.25 \\
& Above 97,000 & 10 & 4.17 \\
& 6.000 & & 2.50 \\
\hline
\end{tabular}

Source: Authors' fieldwork 


\section{Solid Waste Composition and Disposal Methods}

Solid waste is a composition of different materials which are no longer useful to the disposer. In the Lafia metropolis, $51.25 \%$ of the respondents indicated that they generate more food waste (food remains and vegetables). This agrees with the findings of Kabiru (2019) whose study of Gombe town, Nigeria reported 57.9\% for food waste and also Emankhu and Yamusa (2018), whose study of Lafia indicated $67.60 \%$ for biodegradable material (food remains and vegetables). Polythene and plastics constitute $29.59 \%$ of the solid waste composition as reported by the respondents.

The respondents owned one or more types of solid waste storage facilities, most of which were plastic containers $(46.25 \%)$, iron containers $(21.25 \%)$, sack bags $(11.67 \%)$, basket $(8.75 \%)$, drum $(5.83 \%)$, and carton $(4.58 \%)$. The generated solid wastes from households were mainly moved to dumpsites by carrying over the head (41.30\%), by wheelbarrows $(30.45 \%)$, and by pulling the collected waste using sack (15.20\%). $13.05 \%$ of the respondents engaged the services of private waste management companies that evacuate waste storage containers placed at designated houses at the cost of 2,000 to 4,000 Naira monthly.

\section{Location of Dumpsites and Environmental Health Implication}

The location of dumpsites within the Lafia metropolis poses great health implications. Respondents reported that due to the nearness of dumpsites to residences, they have become breeding sites for diseases. $68.25 \%$ of the respondents identified nearness of dumpsites to residence while $21.75 \%$ of the respondents have their dumpsites far away from their residences. The cases of rats and cockroaches invading houses were reported by $59.35 \%$ of the respondents and cases of bad odour within neighbourhoods were imminent as indicated by $62.50 \%$ of the respondents. The cases of disease infections were reported by residents, especially amongst those whose houses were near dumpsites. Malaria constitutes $51.67 \%$ of diseases caused by mosquitoes believed to have found breeding places in dumpsites located near residences.

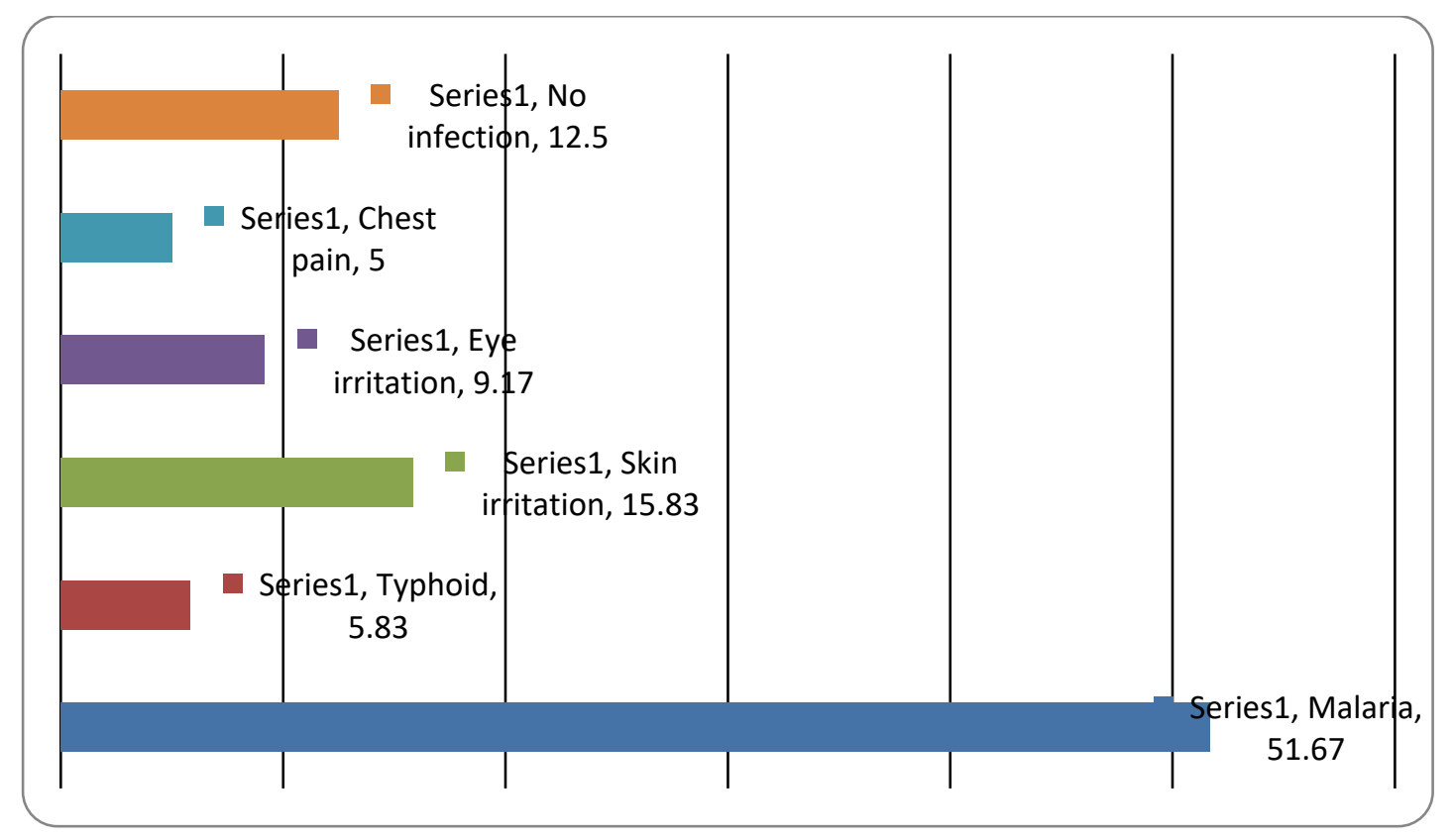

Fig. 3: Percentage distribution of diseases reported by the respondents 
African Journal of Environment and Natural Science Research

ISSN: 2689-9434

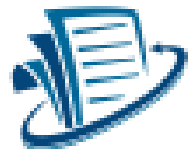

Volume 4, Issue 4, 2021 (pp. 16-26)

www.abjournals.org

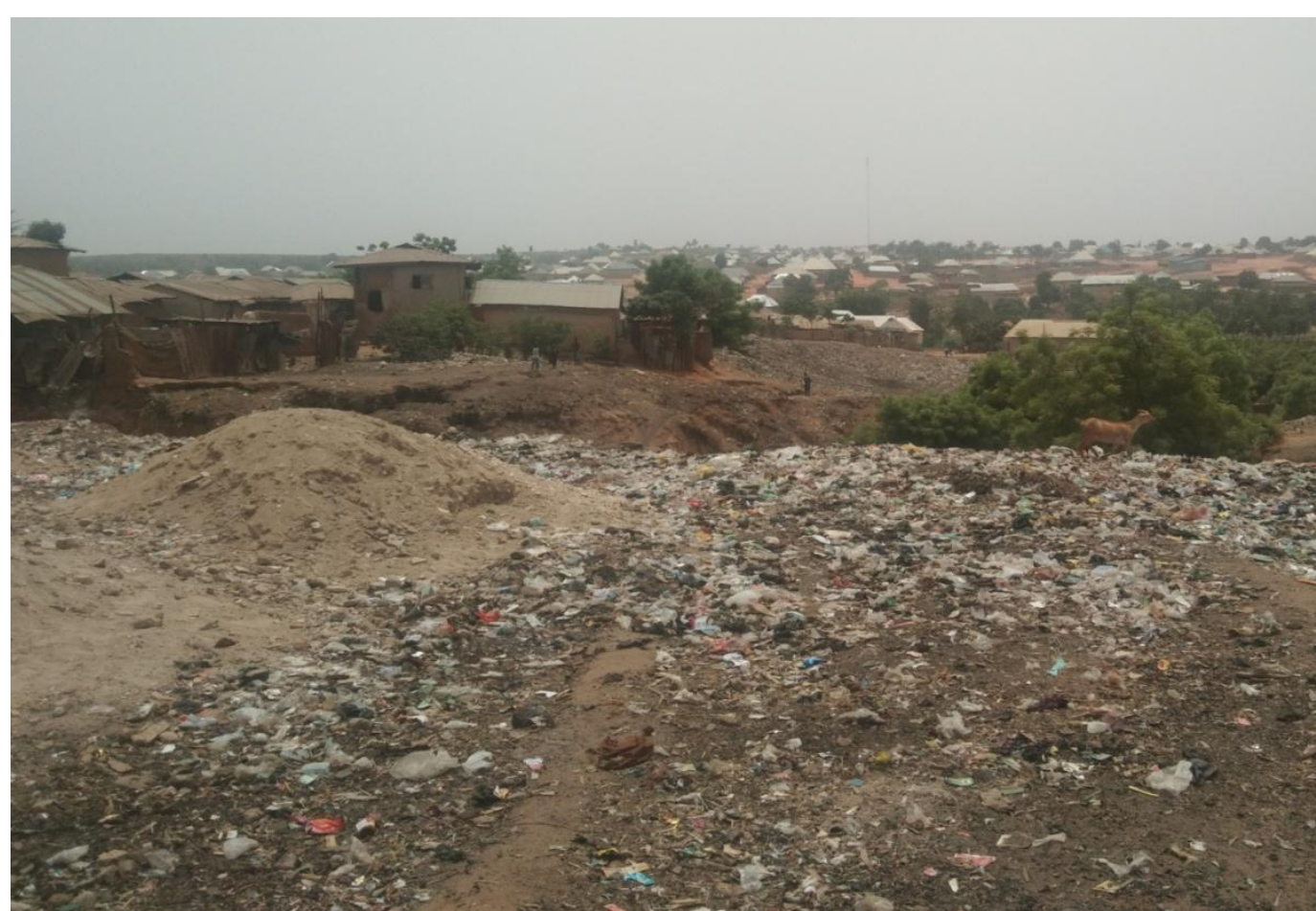

Plate 1: Zanwa dumpsite close to residential houses

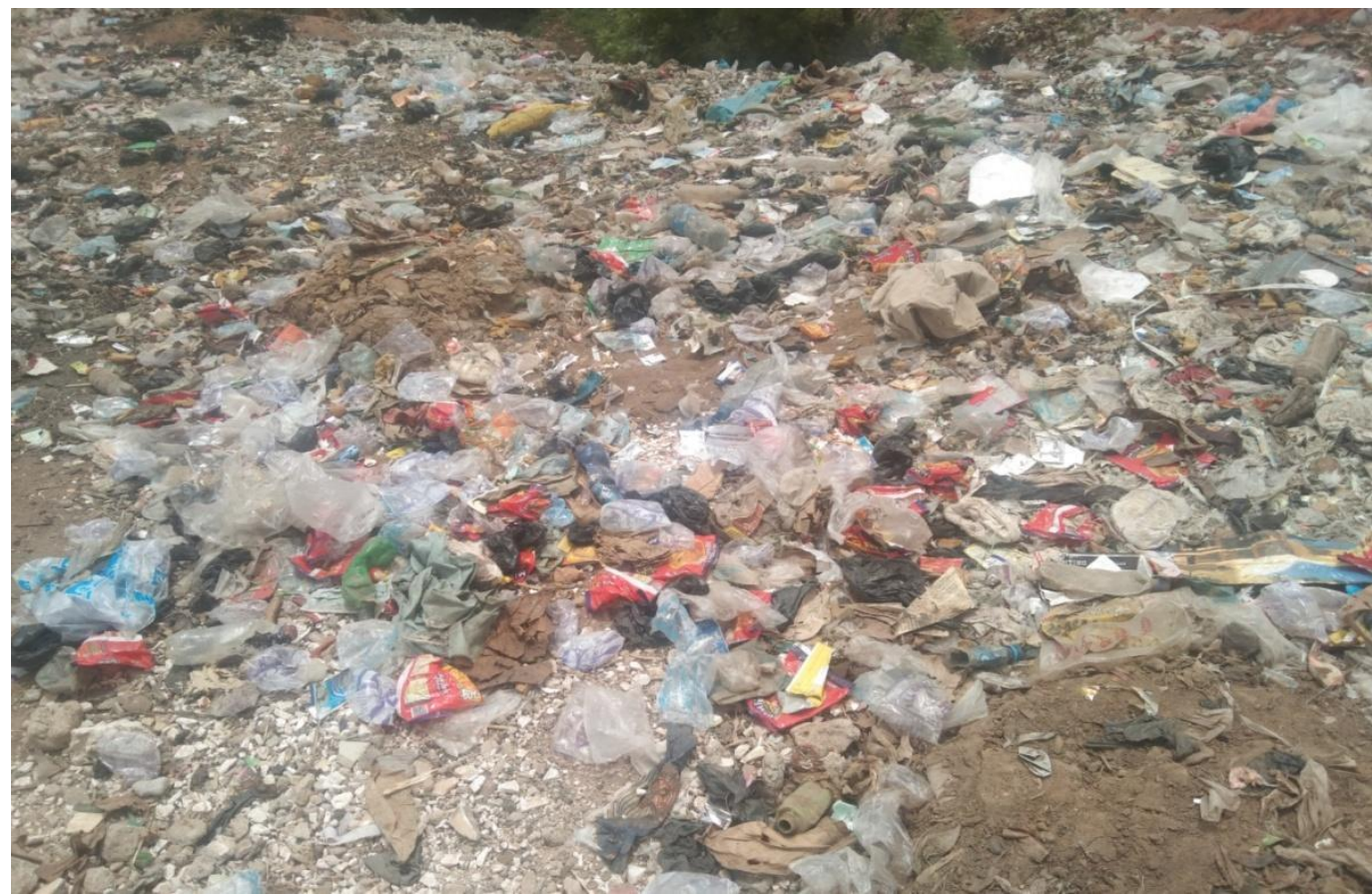

Plate 2: A Dumpsite at Makama ward 
African Journal of Environment and Natural Science Research

ISSN: 2689-9434

Volume 4, Issue 4, 2021 (pp. 16-26)

www.abjournals.org

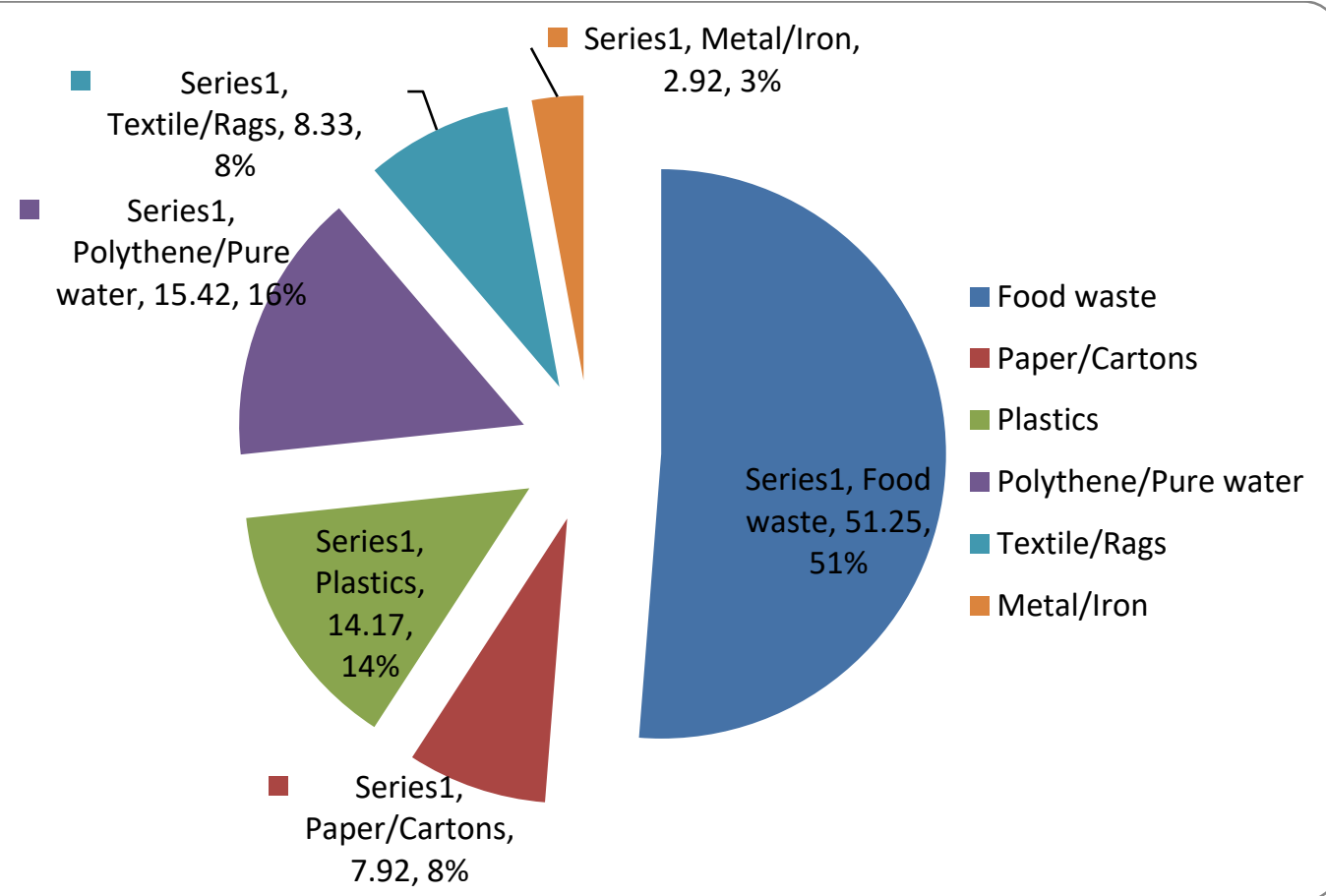

Fig. 4: Percentage distribution of types of solid waste in the study area

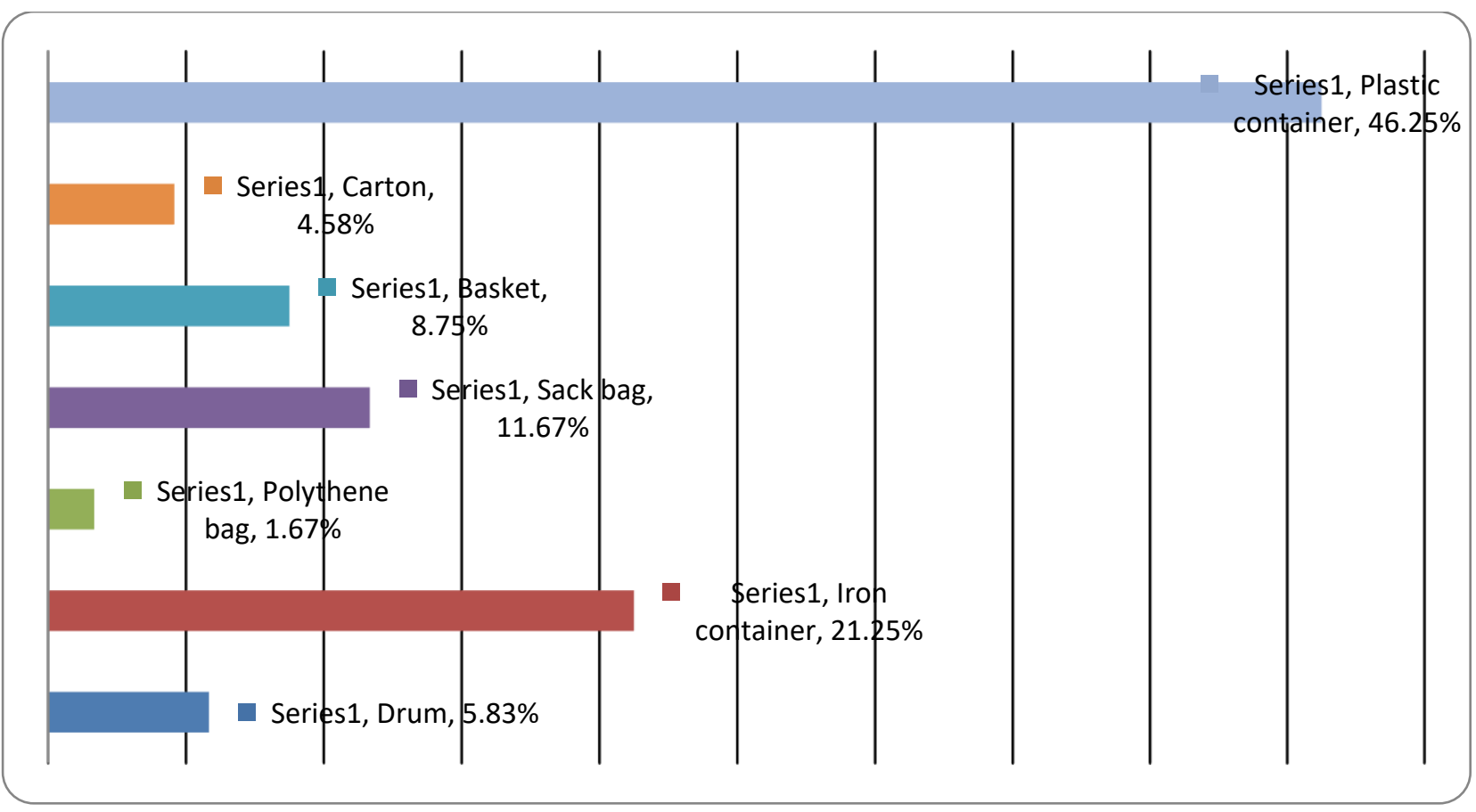

Fig. 5: Percentage distribution of types of storage facilities for solid wastes 


\section{CONCLUSION}

The study investigates the perception of households on the generation and disposal of solid waste in the Lafia metropolis. Occupationally, findings indicate the dominance of persons who are into civil service and business ventures, with a high purchasing power to consume varieties of goods and generate large volumes of waste. It has also been observed that most of the residential houses do not have adequate waste storage facilities and the community dumpsites which appear to be inappropriately located in certain areas within the metropolis, are not usually evacuated by either burning the refuse or the use of vans. Such scenarios have created lots of inconveniences, created breeding sites for disease vectors and scavengers. The attitude of residents to waste disposal poses a great concern to safe and effective solid waste management. Consistent orientation on the need to properly store and dispose of waste should be intensified by relevant agencies including local government authority, religious and traditional heads.

\section{REFERENCES}

Ahmed, S.A., and Ali, M. (2004). Partnership for solid waste management in developing countries: linking theories to realities. Habitat Int., 28(3); 467-479.

Akomolafe, F.G., and Rahmad, Z. (2020). Relating the land-use changes to the invasion of pneumatopteris afra in Nigeria using remote sensing. Pertanika J. Sci. Technol., 28(4); $1345-1365$.

Ali, A.Y., Vivan, E.L., Ombugadu, A., Wambai, M.W., Dahiru, M.K., Njila, H.L. and Mafuyai, M.J. (2016, June). Waste generation, collection and management pattern in Jos city of Plateau State, Nigeria. (Paper presented at the $2^{\text {nd }}$ Annual Conference of Federal University Lafia, Nigeria).

Bello, I.A., Muhamad, N.I. and Nassereldeen, A.K. (2016). Solid waste management in Africa: a review. Int. J. Waste Res., 6(2); 1-4.

Emankhu, S.E. and Yamusa, V.L. (2018). An analysis of municipal solid waste in Lafia, Nasarawa State, Nigeria, West Africa. Int. J. Geog. Reg. Plann. Res., 3(1); 37-46.

Ezekiel, A. and Dominic, A.A. (2014). Sources, demand and problem of domestic water in Nassarawa Eggon town, Nigeria. Pollution, 1(1); 55-65.

Giusti, L. (2009). A review of waste management practices and their impact on human health. Waste management, 29, 2227-2239.

Henry, R.K., Yongsheng, Z. and Jun, D. (2006). Municipal solid waste management challenges in developing countries-Kenyan case study. Elsevier (waste management \& research), 26(1); 92-100.

Kabiru, U.H. (2019). Assessment of the performance of Gombe State Environmental Protection Agency (GOSEPA) on municipal solid waste management in Gombe town, Gombe state, Nigeria. Dissertation, Nasarawa State University, Keffi, Nigeria.

Kumar, S., Bhattacharyya, J.K., Vaidya, A.N., Chakrabarti, T., Devotta, S. and Akolkar, A.B. (2009). Assessment of the status of municipal solid waste management in metro cities, state capitals, class I cities, and class II towns in India: an insight. Elsevier (waste management), 29(2); 883-895.

Minghua, Z., Fan, X., Alberto, R., He, Q., Federico, V., Liu, B., Alessandro, G. and Liu, Y. (2009). Municipal solid waste management in Pudong new area, China. Elsevier (waste management), 29(3); 1227-1233. 
Nag, A. and Vizayakumar, K. (2005). Environmental education and solid waste management. (New Delhi: New Age International Publishers)

National Population Commission (NPC, 2006). National census report. (Abuja, Nigeria)

Nnaji, C.C. (2015). Status of municipal solid waste generation and disposal in Nigeria. Manage. Environ. Quality, 26(1); 53-71.

Ogah, T.A., Alhassan, M.M., Medugu, N.I. and Mohammed, A.B. (2014). Household solid waste management methods in Lafia, Nasarawa State, Nigeria. J. Environ. Sci. Tox. Food Techno., 8(4); 46-51.

Ogah, T.A., Alkali M. and Opaluwa, D.O. (2020). Efficiency of solid waste management methods in Karu local government area, Nasarawa state, north-central, Nigeria. World J. Adv. Res. and Rev., 8(2); 318-329.

Oladipo, O.G., Okoya, A.A., Aladesanmi, O.T. and Ali, G.A. (2011). Policy direction for municipal solid waste management in Nigeria. (In A.T. Salami \& O.O.I. Orimoogunje (Eds.), Environmental research and challenges of sustainable development in Nigeria (pp. 569-584). Obafemi Awolowo University Press, Ile-Ife, Nigeria.)

Sharholy, M., Ahmad, K., Vaishya, R. and Gupta, R. (2007). Municipal solid waste characteristics and management in Allahabad, India. Elsevier (waste management), 27(4); 490-496.

UNEP (2005). Selection, design and implementation of economic instruments in the solid waste management sector in Kenya: the case of plastic bags. UNEP-ETB, Geneva.

World Bank (2019). Solid waste management: understanding poverty and urban development. Retrieved May 17, 2021, from http://worldbank.org/en/topic/urbandevelopment/brief/solid-waste-management

Zaini, S. (2011). Municipal solid waste management in Malaysia: solution for sustainable waste management. J. App. Sci. Environ. Sanit., 6(1); 29-38. 